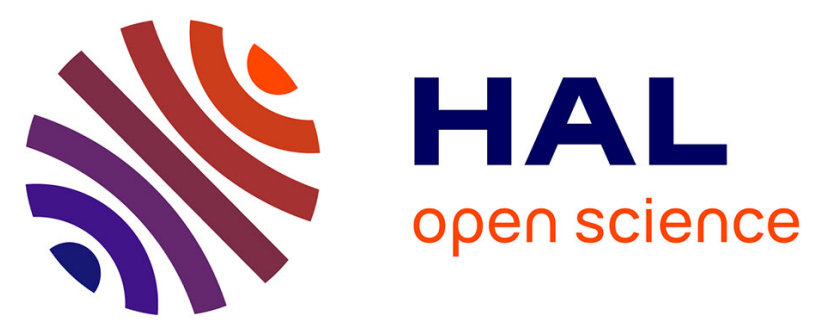

\title{
The impact of Ensemble-Based Assimilation of Thermodynamic Lidar Profiles on Forecasts of the Pre-Convective Environment and Convection Initiation of Heavy Precipitation Events over the Mediterranean region: The German contribution to WaLiNeAs
} Rohith Muraleedharan Thundathil, Thomas Schwitalla, Andreas Behrendt, Diego Lange, Cyrille Flamant, Olivier Caumont, Dave Turner, Volker Wulfmeyer

\section{- To cite this version:}

Rohith Muraleedharan Thundathil, Thomas Schwitalla, Andreas Behrendt, Diego Lange, Cyrille Flamant, et al.. The impact of Ensemble-Based Assimilation of Thermodynamic Lidar Profiles on Forecasts of the Pre-Convective Environment and Convection Initiation of Heavy Precipitation Events over the Mediterranean region: The German contribution to WaLiNeAs. DACH2022 - Kurzfassungen der Meteorologentagung DACH, Mar 2022, Leipzig, Germany. 10.5194/dach2022-238 . insu-03518050

\section{HAL Id: insu-03518050 \\ https://hal-insu.archives-ouvertes.fr/insu-03518050}

Submitted on 8 Jan 2022

HAL is a multi-disciplinary open access archive for the deposit and dissemination of scientific research documents, whether they are published or not. The documents may come from teaching and research institutions in France or abroad, or from public or private research centers.
L'archive ouverte pluridisciplinaire HAL, est destinée au dépôt et à la diffusion de documents scientifiques de niveau recherche, publiés ou non, émanant des établissements d'enseignement et de recherche français ou étrangers, des laboratoires publics ou privés. 


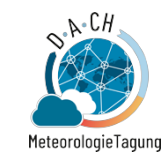

Kurzfassungen der Meteorologentagung DACH DACH2022-238, 2022, updated on 08 Jan 2022 https://doi.org/10.5194/dach2022-238

DACH2022

(C) Author(s) 2022. This work is distributed under the Creative Commons Attribution 4.0 License.

\title{
The impact of Ensemble-Based Assimilation of Thermodynamic Lidar Profiles on Forecasts of the Pre-Convective Environment and Convection Initiation of Heavy Precipitation Events over the Mediterranean region: The German contribution to WaLiNeAs
}

\author{
Rohith Muraleedharan Thundathil ${ }^{1}$, Thomas Schwitalla ${ }^{1}$, Andreas Behrendt ${ }^{1}$, Diego Lange ${ }^{1}$, \\ Cyrille Flamant ${ }^{2}$, Olivier Caumont ${ }^{3}$, Dave Turner ${ }^{4}$, and Volker Wulfmeyer ${ }^{1}$ \\ ${ }^{1}$ University of Hohenheim, Institute of Physics and Meteorology, Stuttgart, Germany (rohith.thundathil@uni-hohenheim.de) \\ ${ }^{2}$ Laboratoire atmosphères, milieux, observations spatiales (LATMOS), France \\ ${ }^{3}$ Centre National de Recherches Météorologiques (CNRM), France \\ ${ }^{4}$ National Oceanic and Atmospheric Administration (NOAA), USA
}

Probabilistic quantitative precipitation forecasting (PrQPF) is a challenging field of meteorology, which is fundamental for the prediction and quantification of extreme precipitation events. With advanced remote-sensing instruments such as lidar systems, it is possible to acquire the highresolution temporal and spatial dynamical and thermodynamic data for input to the numerical weather prediction (NWP) models through data assimilation (DA) techniques. During the fall, the Mediterranean region is often stricken by heavy precipitation events (HPEs), resulting in a sudden rise of water levels in the rivers and flash floods. Severe damage to life and property arises during these extreme precipitation events every year. A unique and innovative French initiative project, called the Water Vapor Lidar Network assimilation (WaLiNeAs), will start a measurement campaign in early September 2022, deploying a network of autonomous water vapor lidars from research groups of France, Germany, and Italy across the Western Mediterranean. The project aims to implement an integrated prediction tool to enhance the forecast of HPEs in southern France, primarily demonstrating the benefit of assimilating vertically resolved water vapor data in the new version of the French operational AROME NWP system. The Atmospheric Raman Temperature and Humidity Sounder (ARTHUS, (Lange et al. 2019)), from the University of Hohenheim (UHOH), will operate in synergy with other lidar systems. The data collected from the measurement campaign, water vapor and temperature, will be assimilated in the Weather Research and Forecasting (WRF) model system at the Institute of Physics and Meteorology (IPM), UHOH. A thermodynamic lidar operator developed by some of us (Thundathil et al. 2020) will be used to assimilate lidar temperature and water vapor mixing ratio independently. The operator avoids undesirable cross sensitivities to temperature enabling maximum moisture information of the observation to be propagated into the model. An advanced hybrid three-dimensional Variational - Ensemble Transform Kalman Filter (3DVAR-ETKF) DA system with 50 ensemble members, on a convection-permitting resolution of $1.5 \mathrm{~km}$, will be set up for the research study. For the prediction and quantification of the HPE event, the assimilation will be performed in a rapid update cycle mode every 15 minutes before its occurrence. A prototype of the DA system with ten ensemble members and a one-hour rapid update cycle was already developed at IPM (Thundathil et al., 2021). In this case, the impact from a single ground-based lidar spreads spatially for a radius of $100 \mathrm{~km}$. Apart from the 
improvement in the analyses, the planetary boundary layer height (PBLH) forecast impact persisted 7 hours into forecast time compared with respect to independent ceilometer observations. The results show a promising initiative for future operational lidar network assimilation. We will present the outline and DA setup of the study, highlighting results from our previous lidar DA research. 